\title{
Increase in the Nitrosamine Content of Several Fish Products upon Broiling
}

\author{
Masami Matsui*1, Hiroshi OHSHIMA ${ }^{* 2}$, and Toshiharu Kawabata ${ }^{* 2}$ \\ (Received December 12, 1979)
}

\begin{abstract}
A total of 20 commercial fish and shellish products consisting of 11 fish species were analyzed before and after broiling on a city gas range for carcinogenic $\mathrm{N}$-nitrosamines by using a nitrosamine specific detection technique (chemiluminescence detection). The mean concentration of $\mathrm{N}$-nitrosodimethylamine (NDMA) in 15 uncooked fish products except dried squids was found to be $2.4 \mu \mathrm{g} / \mathrm{kg}$, and the maximum value found was $9.4 \mu \mathrm{g} / \mathrm{kg}$. The levels of nitrosamines in these products increased remarkably upon broiling, and the average value of NDMA of gas-broiled samples was $6.4 \mu \mathrm{g} / \mathrm{kg}$, and the maximum value found was $26.1 \mu \mathrm{g} / \mathrm{kg}$. The NDMA content of 5 uncooked dried squids ranged from $15.4 \mu \mathrm{g} / \mathrm{kg}$ to $84.0 \mu \mathrm{g} / \mathrm{kg}$, with an average value of $46.3 \mu \mathrm{g} / \mathrm{kg}$; in contrast, those in gas-broiled squids ranged from $23.6 \mu \mathrm{g} / \mathrm{kg}$ to $313 \mu \mathrm{g} / \mathrm{kg}$, with an average value of $130.2 \mu \mathrm{g} / \mathrm{kg}$. Minute quantities of $\mathrm{N}$-nitrosodiethylamine were detected when "akodai" fillets preserved in "sake"-lees were broiled; in addition, $\mathrm{N}$-nitrosopyrrolidine was detected when dried squid samples were broiled on a gas range or even broiled on an electric range. Covering fish products with aluminum foil or broiling them on an electric range was found to be effective in decreasing NDMA formation.
\end{abstract}

It is known that a large proportion of cancers in humans are caused by chemicals in the environment. The high incidence of stomach cancer in Japan has been reported to be associated with the high intake of salt-dried fish and salt-fermented vegetables (pickles) (Sato et al. ${ }^{1,2)}$, HaEnszel et $\left.a l .{ }^{3}\right)$ ). During the past decade, a number of investigations into the occurrence of carcinogenic $N$-nitroso compounds, particularly volatile $N$ nitrosamines in foods have been reported. $\mathrm{Re}$ cently much attention has been paid to the possibility that broiling of fish causes the formation of strong mutagens such as tryptophan pyrolysates (NAGAO et al.$^{4}$, SUGIMURA et al. ${ }^{8)}$, Yamamoto et $\left.a l .^{8)}\right)$. In the present study, we found that some commercial salt-dried fish products contain trace or minute quantities of $\mathrm{N}$-nitrosodimethylamine (NDMA), in addition, the NDMA content increased markedly when these products were broiled on a city gas range.

\section{Experimental}

\section{Food Samples Analyzed}

A total of 20 fish and shellfish products were purchased at several food stores in the Tokyo area. These included following 6 species of salt-dried fish, viz., horse mackerel ("maaji-hiraki", Trachurus japonicus) (3 samples), Pacific saury ("sanma-hiraki", Cololabis saira) (1 sample), chubmackerel ("masaba-hiraki", Pneumatophorus japonicus japonicus) (1 sample), round herring ("urume-iwashi-maruboshi), Etrumeus micropus) (1 sample), "shishamo" (Spirinchus lanceptus) (2 samples), and plainly dried Japanese common squid ("hoshi-surume", Tosarodes pacificus) (5 samples). In addition, analyses were made on the following fish products, viz., tuna ("maguro", Thunnus thynnus) and black cod fillets ("gindara", Anaplopoma firmria) preserved in "miso"-paste, yellow-tail fillets ("buri", Seriola quinqueradiata) seasoned with soy sauce, and "akodai" fillets (Sebastes matsubarai) preserved in "sake"-lees.

\section{Broiling Conditions of Fish Samples}

A total of 20 fish samples (1 to $2 \mathrm{~kg}$ each) consisted of 11 species of fish and shellfish were tested. Half of each sample was analyzed without broiling and the remainder was broiled on a city gas range using an iron fish roaster. After broiling, the meat of the fish was removed, cut into small pieces and thoroughly mixed. In the case of "sanmahiraki" (salt-dried Pacific saury), "urume-iwashi" (salt-dried round herring) and one sample of

*1 Tokyo Research Laboratory, Shimadzu Corporation, 1-63-1 Shibasaki, Chofu-shi, Tokyo 182 (烃居正 已：(侏) 島津製作所東京研究妾)。

*2 Department of Biomedical Research on Foods, National Institute of Health, 2-10-35 Kamiosaki, Shinagawa-ku, Tokyo 141 （大島寛史・河端俊治：国立予防衛生研究所食品衛生部）。 
"hoshi-surume" (dried squid), one quarter of each sample was covered with aluminum foil, and then broiled on a gas range; a 2nd quarter was broiled on a gas range as mentioned above; a 3rd quarter was broiled directly on an electric range, and the last quarter was analyzed without broiling.

\section{Nitrosamine Analysis}

For the preparation of the test solutions, a $40 \mathrm{~g}$ sample was homogenized in a mechanical blender with $8 \mathrm{~m} l$ of aqueous solution containing $2 \mathrm{~g}$ of ammonium sulfamate and $1 \mathrm{~m} l$ of internal standard solution $\left(0.4 \mu \mathrm{g} / \mathrm{m} l-\mathrm{CH}_{2} \mathrm{Cl}_{2}\right.$ of nitrosodi-iso-butylamine; NDiBA). This was then left standing for $10 \mathrm{~min}$. Next, $8 \mathrm{~g}$ of $\mathrm{KOH}, 30 \mathrm{~g}$ of anhydrous $\mathrm{Na}_{2} \mathrm{SO}_{4}$ and $80 \mathrm{~m} l$ of $\mathrm{CH}_{2} \mathrm{Cl}_{2}$ were added to the homogenate, and the mixture was homogenized for $3 \mathrm{~min}$. The $\mathrm{CH}_{2} \mathrm{Cl}_{2}$ layer was separated by filtration through filter paper. This extraction was performed 3 times. The combined $\mathrm{CH}_{2} \mathrm{Cl}_{2}$ extracts were dried over anhydrous $\mathrm{Na}_{2} \mathrm{SO}_{4}$, followed by concentration to $3 \mathrm{~m} l$ in a KudernerDanish (K-D) evaporative concentrator. The concentrate was kept in a glass ampule at $-20^{\circ} \mathrm{C}$ until it was analyzed by gas chromatography. For the preparation of test solution from fish products containing relatively large amounts of oil, a $40 \mathrm{~g}$ well-minced sample to which $1 \mathrm{~m} l$ of internal standard $(0.4 \mu \mathrm{g}$ of NDiBA) had been added was quickly frozen with an appropriate volume of liquid nitrogen and then $100 \mathrm{~m} l$ of $\mathrm{CH}_{2} \mathrm{Cl}_{2}$ pre-chilled with dry ice was added to the frozen sample. This was then homogenized for $3 \mathrm{~min}$. The $\mathrm{CH}_{2} \mathrm{Cl}_{2}$ layer was separated by filtration through filter paper. The extraction procedure was performed 3 times. The combined $\mathrm{CH}_{2} \mathrm{Cl}_{2}$ extracts were evaporated to $3 \mathrm{ml}$ in a $\mathrm{K}-\mathrm{D}$ concentrator. A Shimadzu GC-6AM gas chromatograph equipped with a thermal energy analyzer (TEA-502, Thermo Electron Corp., Mass., USA) was used for gas chromatographic analysis of nitrosamines. A glass column ( $3 \mathrm{~mm}$ i.d., $\times 2 \mathrm{~m}$ ) packed with $10 \%$ PEG-20M on Chromosorb W (60-80 mesh) was employed. The carrier gas was argon delivered at a flow rate of $40 \mathrm{~m} / / \mathrm{min}$. The temperatures of the injection port and column oven were $280^{\circ}$ and $160^{\circ} \mathrm{C}$ respectively. The temperatures of the analytical pyrolyzer and cold trap were $450^{\circ}$ and $-160^{\circ} \mathrm{C}$.

\section{Results}

The results of nitrosamine analysis of various fish products before and after broiling are summarized in Table 1. Of the 15 uncooked samples of the 10 different fish products excepting dried squid samples, $7(47 \%)$ were found to contain N.D. to $0.5 \mu \mathrm{g} / \mathrm{kg}$ levels of NDMA, and those levels in the remainder ranged from 1.0 to $9.4 \mu \mathrm{g} / \mathrm{kg}$, with an average value of $2.4 \mu \mathrm{g} / \mathrm{kg}$. The NDMA levels in the 5 uncooked dried squids ranged from 15.4 to $84.0 \mu \mathrm{g} / \mathrm{kg}$, with an average value of $46.3 \mu \mathrm{g} / \mathrm{kg}$. Trace quantities of $N$-nitrosodiethylamine (NDEA) were detected only in two samples of "akodai" fillets preserved in "sake"-lees.

It was found that the NDMA content of these fish products apparently increased upon broiling on a gas range using an iron fish roaster. However, as shown in Table 1, considerable variation was observed in the degree of increase in NDMA according to the fish species. Only slight increase in the NDMA content could be detected in the samples of relatively high moisture content such as fish fillets preserved in "miso"-paste, soy sauce or "sake"-lees, in contrast, when lower moisture content products such as salt-dried fish and plainly dried squid were broiled, the NDMA content markedly increased, and the levels were raised 1.5 to 23.8 times (average, 4.9 times) higher than those of original uncooked products. Especially, this tendency was conspicuous when dried squids were broiled on a gas range, and both NDMA and $N$-nitrosopyrrolidine (NPYR) were found to increase markedly. It is also to be noted that the NDEA content of "akodai" fillets preserved in "sake"-lees apparently increased when these were cooked on a gas range. When cooking the fish, it has been found that covering the fish with aluminum foil or broiling it on an electric range is effective in decreasing NDMA formation.

\section{Discussion}

The results of the present survey on volatile nitrosamines in commercial fish products (uncooked) almost coincided with the levels reported previously in cured meat products ${ }^{7,87}$, cheeses ${ }^{9)}$, beers $^{10,11)}$ and fish products ${ }^{12,13}$. However, uncooked dried squids were found to contain fairly large amounts of NDMA ranging from 15.4 to $84.0 \mu \mathrm{g} / \mathrm{kg}$, and NDMA formation in these products might be related to their manufacturing process. Although further experiments are needed to elucidate the exact reason (s) for the NDMA formation in dried squids, one most possible mechanism of it seems to be caused by the drying 
Table 1. Changes in $N$-nitrosamine contents of fish products upon broiling

\begin{tabular}{|c|c|c|c|c|}
\hline \multirow{2}{*}{ Sample } & \multirow{2}{*}{ Method of broiling } & \multicolumn{3}{|c|}{ Nitrosamine content $(\mu \mathrm{g} / \mathrm{kg})$} \\
\hline & & NDMA & NDEA & NPYR \\
\hline \multirow{4}{*}{$\begin{array}{c}\text { Tuna fillets preserved in "miso" } \\
\text { paste, "Maguro-miso zuke" }\end{array}$} & (1) uncoocked*1 & 3.0 & N.D. & N.D. \\
\hline & gas $^{* 2}$ & 9.4 & - & - \\
\hline & (2) uncooked & 4.7 & - & - \\
\hline & gas & 7.0 & - & - \\
\hline \multirow{8}{*}{$\begin{array}{l}\text { Black cod fillets preserved in } \\
\text { "miso" paste, "Gindara-misozuke" } \\
\text { Yellowtail fillets seasoned with soy } \\
\text { sauce, "Buri-shyoyuzuke" } \\
\text { "Akodai" fillets preserved in } \\
\text { "sake"-lees, "Akodai"--kasuzuke }\end{array}$} & uncooked & tr. & N.D. & N.D. \\
\hline & gas & $\operatorname{tr}$ & - & - \\
\hline & uncooked & N.D. & N.D. & N.D. \\
\hline & gas & - & - & - \\
\hline & (1) uncooked & tr. & 0.3 & N.D. \\
\hline & gas & 5.4 & 4.7 & - \\
\hline & (2) uncooked & tr. & 3.7 & - \\
\hline & gas & 2.0 & 14.2 & - \\
\hline \multirow{7}{*}{$\begin{array}{l}\text { Salt-dried horse mackerel, } \\
\text { "Ajihiraki" }\end{array}$} & (1) uncooked & 1.0 & N.D. & N.D. \\
\hline & gas & 6.0 & - & - \\
\hline & (2) uncooked & 2.4 & - & - \\
\hline & gas & 7.8 & - & - \\
\hline & (3) uncooked & 4.9 & - & - \\
\hline & Al-foil ${ }^{* 3}$ & 3.4 & - & - \\
\hline & electric*4 & 5.9 & - & - \\
\hline \multirow[t]{4}{*}{ Salt-dried "Shishamo" } & (1) uncooked & 0.5 & N.D. & N.D. \\
\hline & gas & 1.0 & - & - \\
\hline & (2) uncooked & 4.0 & - & - \\
\hline & gas & 13.0 & - & - \\
\hline \multirow{4}{*}{$\begin{array}{l}\text { Salt-dried Pacific saury, } \\
\text { "Sanma-hiraki"" }\end{array}$} & uncooked & $\operatorname{tr}$ & N.D. & N.D. \\
\hline & Al-foil & 3.7 & - & - \\
\hline & electric & 1.1 & - & - \\
\hline & gas & 6.8 & - & - \\
\hline \multirow{2}{*}{$\begin{array}{l}\text { Salt-dried flounder, } \\
\text { "Karei-himono" }\end{array}$} & uncooked & N.D. & N.D. & N.D. \\
\hline & gas & tr. & - & - \\
\hline \multirow{4}{*}{$\begin{array}{l}\text { Salt-dried chubmackerel, } \\
\text { "Saba-hiraki" }\end{array}$} & uncooked & 0.5 & N.D. & N.D \\
\hline & Al-foil & 5.8 & - & - \\
\hline & electric & 7.3 & - & - \\
\hline & gas & 11.9 & - & - \\
\hline \multirow{4}{*}{$\begin{array}{l}\text { Salt-dried round herring, } \\
\text { "Urumeiwashi-maruboshi" }\end{array}$} & uncooked & 5.0 & N.D. & N.D. \\
\hline & Al-foil & 2.5 & - & - \\
\hline & electric & 4.5 & - & - \\
\hline & gas & 26.1 & - & - \\
\hline \multirow[t]{12}{*}{ Dried squid, "Hoshi-surume" } & (1) uncooked & 15.0 & N.D. & N.D. \\
\hline & gas & 23.6 & - & 7.2 \\
\hline & (2) uncooked & 58.4 & - & N.D. \\
\hline & gas & 135.2 & - & 2.4 \\
\hline & (3) uncooked & 84.0 & - & N.D. \\
\hline & gas & 313.1 & - & 9.7 \\
\hline & (4) uncooked & 55.8 & 一 & N.D. \\
\hline & gas & 110.1 & - & 12.9 \\
\hline & (5) uncooked & 17.8 & - & N.D. \\
\hline & Al-foil & 14.3 & - & - \\
\hline & electric & 48.4 & 一 & 3.7 \\
\hline & gas & 68.8 & - & 3.3 \\
\hline
\end{tabular}

*1 uncooked; original uncooked product, *2 gas; samples were broiled on a city gas range using an iron fish roaster,

*3 samples covered with aluminum foil were broiled in a gas range, *4 electric; samples were broiled on an electric range.

Detection limit. of nitrosamines: $0.5 \mu \mathrm{g} / \mathrm{kg}$ for NDMA and NDEA; $1 \mu \mathrm{g} / \mathrm{kg}$ for NPYR. 
process. It is to be noted that traditional uncooked dried squid (prepared by drying eviscerated squid meat in the sun) contains no detectable nitrosamine. Recently, however, these products are prepared by an artificial drying system, viz., raw squid meat is dried in a room ventilated with warm, dry air. Sometimes the air is heated directly by oil burner, and nitrogen oxides derived from the combustion process may react with amines (trimethylaminoxide, trimethylamine and dimethylamine) in the squid meat to give NDMA.

When cooking the dried fish on a city gas range, a marked increase in the NDMA content was observed. The reason for the NDMA formation during broiling of fish products might be attributable to nitrogen oxides derived from the combustion of city gas, and nitrogen oxides may easily react with amines in the fish to give nitrosamines. This was confirmed by the following experiments, viz., covering the fish with aluminum foil or broiling it on an electric range was effective in decreasing NDMA formation. The reactions of gaseous nitrosating species such as $\mathrm{N}_{2} \mathrm{O}_{3}$ and $\mathrm{N}_{2} \mathrm{O}_{4}$ with amines to yield $N$-nitroso compounds were reported by NeURATH et al. ${ }^{14}$ ), GeHLert and Rolle ${ }^{15}$ ) and Challis and Kyrtopoulos ${ }^{18)}$. Recently, the contamination of beer with with NDMA has been reported by PREUSSMANN and his colleagues ${ }^{10,17}$, and KaWABATA et al. ${ }^{11}$. As to the origin and formation of NDMA in German beer, PREUSSMANN et al. ${ }^{17)}$ reported that the method of heating of the malt during kilning may significantly affect NDMA formation. The hot air stream used to dry the malt is very often heated by direct firing techniques, and nitrogen oxides formed from air might be the main source of NDMA formation, and this phenomenon coincides with that occurring in the preparation of dried squid by an artificial drying system or broiling fish products on a gas range.

It is rather difficult to assess the biological implications of the consumption of fish products containing low levels of nitrosamines by man. Since nitrosamines are known to be potent carcinogens in experimental animals, it is necessary to develop an appropriate method to minimize nitrosamine contents of various fish products. In this context, we should reconsider the present artificial drying system especially adopted by the preparation of dried squids. In addition, studies designed to prevent or minimize nitrosamine formation during broiling fish products are urgently required from the public health standpoint.

\section{References}

1) T. Sato, T. Fukuyama, T. Suzuki, and J. TAKaYANAGI: Bull. Inst. Publ. Health, (Japan), 8, 187-198 (1959).

2) T. Sato, T. FukuYama, T. Suzuki, and J. Takayanagi: Bull. Inst. Publ. Health, (Japan), 10, 9-17 (1961).

3) W. Haenszel, M. Kurihara, M. Segi, and R. K. C. LEE: J. Natl. Cancer Inst., 49, 969-988 (1972).

4) M. Nagao, M. Honda, Y. Seino, T. Yahagi, T. KAWACHI, and T. Sugimura: Cancer Letters, 2 , 235-240 (1977).

5) T. Sugimura, T. Kawachi, M. Nagao, T. Yahagi, Y. Seino, T. OKamoto, K. Shudo, T. Kosuge, K. Tsuji, K. Wakabayashi, Y. Ittake, and A. ITAI: Proc. Japan Acad., 53, 58-61 (1977).

6) T. Yamamoto, K. Tsuj, T. Kosuge, T. Okamoto, K. TAkeda, and T. Sugimura: Proc. Japan Acad., 54, 248-250 (1978).

7) N. P. SEN: Fd. Cosmet. Toxicol, 10, 219-223 (1972).

8) D. C. Havery, T. Fazio, and J. W. Howard: J. Assoc. Off. Anal. Chem., 61, 1374-1378 (1978).

9) R. W. Stephany, R. H. C. Elgersma, and R. L. SchUlLER: Neth. Milk Dairy J., 32, 143-148 (1978).

10) B. Spiegelhalder, G. Eisenbrand, and R. Preussmann: Fd. Cosmet. Toxicol., 17, 29-31 (1979).

11) T. Kawabata, H. Ohshima, J. Uibu, M. NaKamura, M. Matsut, and M. Hamano: in "Natlrally Occurring Carcinogens-Mutagens and Modulators of Carcinogenesis" (ed. by E. C. Miller, J. A. Miller, I. Hirono, T. Sugimura, and S. TAKAYAMA), Japan Sci. Soc. Press, Tokyo, 1979, pp. 195-206.

12) J. R. Iyengar, T. Panalaks, W. F. Miles, and N. P. SEN: J. Sci. Fd. Agric., 27, 527-530 (1976).

13) D. C. HAVERY and T. FAZIo: J. Assoc. Off. Anal. Chem., 60, 517-519 (1977).

14) G. B. Neurath, M. Dunger, and F. G. Pein: in "Environmental N-Nitroso Compounds-Analysis and Formation" (ed. by E. A. WALKRR, P. BogovskI, and L. GRICIUTE), IARC Scientific Publications No. 14, International Agency for Research on Cancer, Lyon, France, 1976, pp. 227-236.

15) P. Gehlert and W. Rolle: Experientia, 33, 579 (1977).

16) B. C. Challis and S. A. Kyrtopoulos: Br. J. Cancer, 35, 693-696 (1977).

17) R. Preussmann, B. Spirgelhalder, G. EisenBRAND, and C. JANZOWSKI: in "Naturally Occurr" ing Carcinogens-Mutagens and Modulators of Carcinogenesis" (ed. by E.C. Miller, J.A. MuLer, I. Hirono, T. Sugmura, and S. Takayama), Japan. Sci. Soc. Press, Tokyo, 1979, pp. 185-194. 